\title{
Strategic planning IS/IT TO improve business competitiveness in public hospital
}

\author{
Muhammad Ridho Bintang ${ }^{*}$, Febriliyan Samopa ${ }^{2}$, Rita Ambarwati ${ }^{3}$ \\ Department of Technology Management, Institut Teknologi Sepuluh Nopember, Indonesia \\ Department of System Information, Institut Teknologi Sepuluh Nopember, Indonesia ${ }^{2}$ \\ Faculty of Business Law and Social Science, Universitas Muhammadiyah Sidoarjo, Indonesia ${ }^{3}$
}

\section{Article Info}

Keywords:

Cost-Benefit Analysis, IS / IT Strategy, Public

Hospital, Strategic Planning, Ward and

Peppard

\section{Article history:}

Received: December 17, 2020

Accepted: January 14, 2021

Published: February 28, 2021

Cite:

Bintang Janaputra, M. R., Samopa, F., \& Ambarwati Sukmono, R. (2021). The Strategic

Planning IS/IT TO Improve Business

Competitiveness in Public Hospital. Kinetik:

Game Technology, Information System,

Computer Network, Computing, Electronics, and Control, 6(1).

https://doi.org/10.22219/kinetik.v6i1.1181

${ }^{*}$ Corresponding author.

Muhammad Ridho Bintang

E-mail address:

ridhobintang12@gmail.com

\begin{abstract}
Hospital competition is getting tighter, making good hospital strategic planning very important so that the Hospital can survive to develop better in a changing environment. Today's competitive advantage cannot be separated from Information Systems (IS) and Information Technology (IT). IS / IT in hospitals is currently used as a tool to create and develop innovative products, systems, and services for hospitals. The problem that occurs today is a large number of IS / IT that is made without looking at the financial side of the Hospital, thus making a number of uses of IS / IT not optimal in Hospital operational and business activities. Based on these problems, IS / IT strategic planning that also considers financial capability is needed. In this research, IS/IT strategic planning that takes into account the financial aspects is achieved using the approach of Ward and Peppard combined with Cost-Benefit Analysis. Value Chain and Critical Success Factor (CSF) analysis methods are used to analyze the current internal condition of the Hospital. Meanwhile, PEST and Porter's Five Forces analysis used external business analysis of the Hospital. The results of this study are in the form of IS business strategy recommendations, IS/IT management strategies, IT strategies, IS application portfolios, and IS/IT investment roadmaps compiled based on costs and benefits. There are 25 IS strategy recommendations, the IT strategy recommends 14 proposals to support the IS strategy based on the cost-benefit, and the IS / IT management strategy recommendations consist of 16 suggestions to support the IS strategy and IT strategy.
\end{abstract}

\section{Introduction}

The Hospital is a form of health service institution that provides complete individual health services that provide inpatient, outpatient, and emergency services [1]. The increasing number of hospitals makes each Hospital compete with each other for customers. In Indonesia, hospitals have experienced rapid growth from time to time. Data from the Directorate General of Health Care shows that there are 2,889 hospitals in Indonesia, an increase of $27 \%$ over 2012 of 2083 hospitals [2][3][4]. Along with this growth, there is intense competition for hospitals to win the market in the hospital industry. It can also be seen that many public hospitals have been pushed to become organizations that fully manage their own finances.

The status of financial management itself makes many hospitals have to be smart in managing their finances, especially during this pandemic, many people avoid hospitals, making hospital income drastically reduced. This is what makes hospitals compete with each other to gain a competitive advantage in financial constraints [5][6]. The importance of good Hospital strategic planning is needed to survive in the competition and develop better in a changing environment [7]. In achieving a competitive advantage, it is necessary to have creativity and innovation in the Hospital [8]. Meanwhile, today's competitive advantage cannot be separated from the strategic planning of Information Systems (IS) and Information Technology (IT). Information technology in today's competitive industry plays an important role, including the hospital industry [9]. One form of hospital strategic planning that is related to IS / IT is to improve the quality of hospital services by using the Hospital Management Information System (SIMRS). SIMRS is a procedure for processing data by utilizing integrated IS / IT to obtain accurate and effective information results. In addition to improving the quality of hospital services, IS / IT is used as a tool for making and developing innovation in a hospital. The information system (SI) defines what the hospital needs. Information technology (IT) is more focused on meeting hospital demands, such as in terms of hardware [10].

All hospitals, including regional general hospitals (RSUD), require IS / IT strategic planning as a means of increasing their competitive advantage. The output produced by IS / IT strategic planning is a portfolio recommendation. This portfolio recommendation is used as a reference for hospitals as a tool to improve hospital services. The resulting portfolio recommendations are not the same depending on the needs of the Hospital itself. This study uses the cost-

Cite: Bintang Janaputra, M. R., Samopa, F., \& Ambarwati Sukmono, R. (2021). The Strategic Planning IS/IT TO Improve Business Competitiveness in Public Hospital. Kinetik: Game Technology, Information System, Computer Network, Computing, Electronics, and Control, 6(1). https://doi.org/10.22219/kinetik.v6i1.1181 
benefit analysis method in determining the costs and benefits of strategic planning results. Several previous studies, such as Sriminangga's research, carried out IS / IT strategic planning at Kominfo Malang. This study uses the Ward \& Peppard method with the addition of Value Chain analysis, Critical Success Factor (CSF), and Gap analysis [11]. There are also those who add a Balance Scorecard in the Ward \& Peppard method to carry out IS / IT strategic planning, such as the research of Setiawan and Hannesto [12][13]. In the same year, Christianti's research added a SWOT analysis to analyze the internal business of a company at Ward \& Peppard [14]. In Ismanto's research, he used Ward \& Peppard in IS / IT strategic planning to increase competitiveness at Balitbangtan at the Ministry of Agriculture [15]. In Budiyanto's research, IS / IT strategic planning carried out at the Yogyakarta "API" Polytechnic besides adding SWOT to the Ward \& Peppard method, researchers also added McFarlan Strategic Grid to assess or map current applications that fall into the high potential, strategic, key operational or support [16]. Complementing his previous research, Febriyanti complements his research on IS / IT strategic planning by incorporating all analyzes from previous research and adding it to PEST analysis and Five Forces analysis as a solution to analyzing internal and external business environments [17]. Updates were made to Lestari's research using the Ward \& Peppard framework and adding the Anita Cassidy method. Lestari's research results are IS business strategy, IT strategy, IS application portfolio, and recommendations for the amount of costs needed and applications that can be implemented [18]. Unlike some previous studies that used the Ward \& Peppard method to determine IS / IT strategic planning regardless of the financial side. A large number of previous studies resulted in portfolio recommendations without looking at the financial side, which caused many not to be implemented due to hospital financial constraints. Based on these problems, this study will discuss IS / IT strategic planning based on costs and benefits. This study uses the Ward and Peppard method to analyze hospital strategic planning. Meanwhile, to determine the cost-benefit of the resulting portfolio recommendations using the cost-benefit analysis method.

\section{Methods}

This research was carried out in several stages. These stages are the introduction stage, the stage of data collection and analysis, the analysis stage of the current business environment conditions, the stage of IS / IT environmental conditions, the stage of determining future needs, the stage of strategy formulation, the cost-benefit analysis. The strategic planning research framework can be seen in Figure 1.

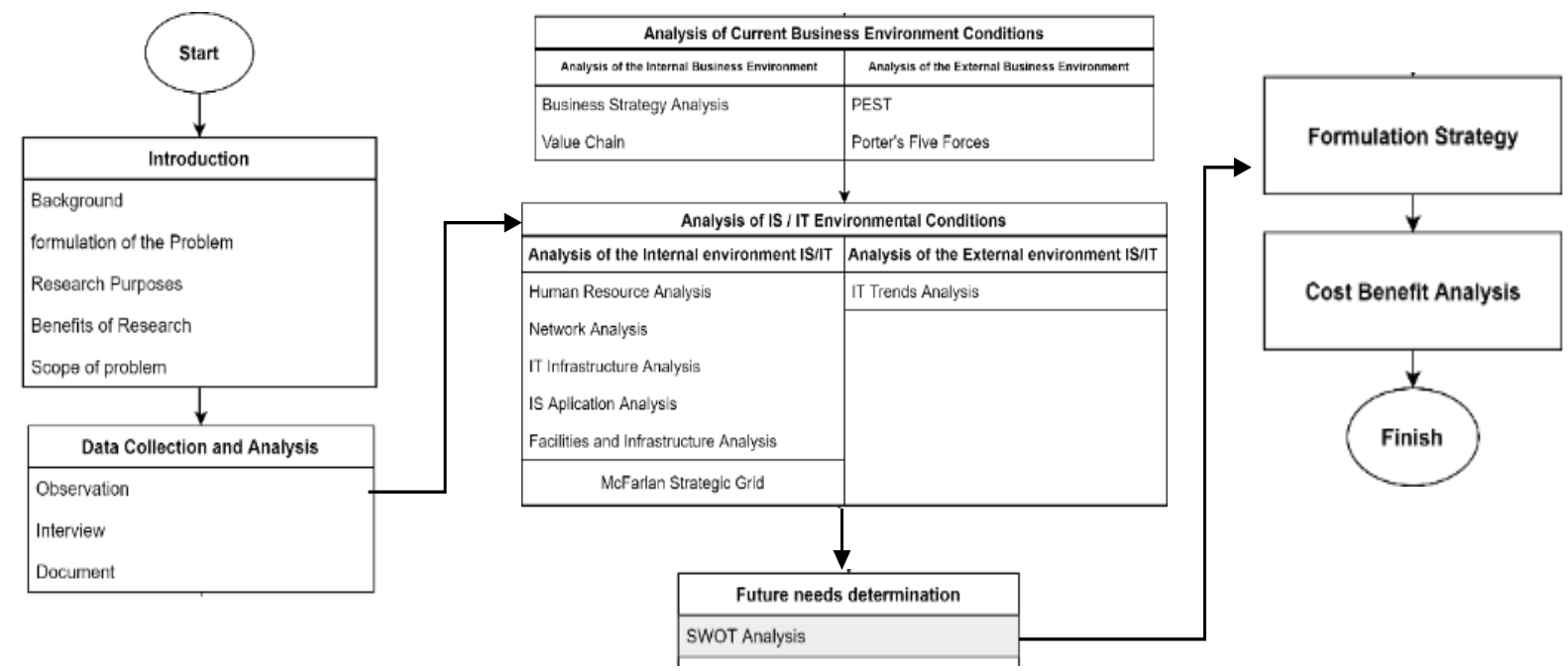

Figure 1. IS / IT Strategic Planning Research Framework

The first stage is the stage of data collection and analysis. This stage is the stage of collecting data related to the research object, namely the regional public Hospital (RSUD). Data collection was carried out by conducting interviews, a literature study of related documents, and observation. The second stage is an analysis of the current environmental conditions. At this stage, the researcher analyzes and understands the current conditions and implements business needs. This stage includes several steps, namely analyzing the internal and external business environment, analyzing the external and internal IS / IT environment. To analyze the internal business environment using value chain and business strategy analysis [19]. Meanwhile, to analyze the external environment of the business using PEST and Porter Five Forces [20]. Analysis of the internal IS / IT environment, which functions to compare the current IS / IT condition with the goals that the RSUD will achieve in the future. This analysis includes the evaluation of all IS / IT resources in the RSUD, such as evaluating the application portfolio, resources, infrastructure, and services. The technique used to analyze is the analysis of human resources, networks, IT infrastructure, IS applications, facilities, and infrastructure [21].

(c) 2021 The Authors. Published by Universitas Muhammadiyah Malang

This is an open access article under the CC BY SA license. (https://creativecommons.org/licenses/by-sa/4.0/) 
Then use the Mcfarlan strategic grid analysis to map the IS / IT application based on its contribution to the RSUD. Meanwhile, the analysis of the external IS / IT environment is carried out using information technology trend analysis. This analysis is used to obtain potential applications in the future. The third stage is the stage of determining future needs. At this stage, the conditions expected by the Hospital will be explained through a series of IS / IT needs analysis using a SWOT analysis. SWOT analysis is used to map the strengths, weaknesses, opportunities, and threats that the Hospital has. The fourth stage is the strategy formulation stage. At the strategy formulation stage, IS / IT planning produces three outputs, namely IS / IT strategic management, IS business strategy, and IT strategy [22][23]. The three outputs resulted in recommendations in the form of a portfolio that would be applied to improve hospital business activities in the future [24][25].

After getting portfolio recommendations, the Cost-Benefit Analysis (CBA) stage is carried out. CBA is a tool used to assess the feasibility of a plan, program, or investment [26]. CBA is also used to assist in making decisions and assessing available alternatives [27]. There is a conceptual framework in using the CBA method in this study, starting from determining all benefits (direct benefits or indirect benefits). The method used for this cost-benefit study is based on three economic criteria such as NPV, IRR, and the payback period can be seen in Table 1.

Table 1. Economic Criteria

\begin{tabular}{ccc}
\hline No. & Economic Criteria & Parameters \\
\hline 1 & Net Present Value & NPV $>0$ \\
2 & Payback period & Life cycle project max 5 years \\
3 & Internal rate of return & IRR $>$ Discount rate $4 \%$ \\
\hline
\end{tabular}

The NPV is a measure of profitability and is used to assess the potential ROI of a particular project. A positive NPV indicates that the projected revenue generated by the project or investment exceeds the anticipated costs [28]. IRR is a discount rate that equates initial outlays with the present value of future cash flows [29]. The values required in this calculation are the positive and negative NPV and discount rate values. The payback period shows the number of years it takes for a project or investment to depreciate. the closer to 0 , the better the investment is carried out.

\section{Result and Discussion}

\subsection{Internal Business Environment Analysis}

The first step in this research is to use business strategy analysis. This analysis looks at the vision, mission, and company values that have been set by the RSUD management. There are ten results of business strategy analysis, and among them, all health services have standard systems, mechanisms, and procedures, according to the Decree of the Director of the Regional General Hospital, dr. Iskak Tulungagung No: 188.4 / 44 / Director / 206/2019. Improving the Hospital's quality includes handling complaints, suggestions, and input, completing each service with facilities, infrastructure and/or facilities, and carrying out internal supervision. Carrying out quality education and research by improving the quality and quantity of health workers according to service standards towards type A hospitals. RSUD dr. Iskak gets KARS and does regular accreditation every three years through the Hospital Accreditation Commission (KARS). The analysis further value chain carried out to determine the business Hospital and also charted the process of business to the activities major and activity support. There are two parts in the analysis of the value chain, the activity of the main (Primary Activities) and activity support (Support Activities). The results of the analysis of the value chain are obtained can be seen in Figure 2.

\begin{tabular}{|c|c|c|c|c|}
\hline \multicolumn{5}{|c|}{$\begin{array}{l}\text { Firm Infrastructure } \\
\text { - All financial matters from accounting, receiving, treasury, and financial verification. } \\
\text { - Supervision of the quality and performance of each service and standard hospital standards } \\
\text { - Prevention and control of disease }\end{array}$} \\
\hline \multicolumn{5}{|c|}{$\begin{array}{l}\text { Human Resource Management } \\
\text { - Recruitment of honorary employees } \\
\text { - Management of attendance, leave, permits, external service and job mapping }\end{array}$} \\
\hline \multicolumn{5}{|c|}{$\begin{array}{l}\text { Technology Development } \\
\text { - Development of IS / IT such as hospital websites, medical records, application support services for health services } \\
\text { - Technology development and research in the field of medicine }\end{array}$} \\
\hline \multicolumn{5}{|c|}{$\begin{array}{l}\text { Procurement } \\
\text { Procurement of goods and services through LPSE electronic procurement }\end{array}$} \\
\hline $\begin{array}{l}\text { INBOUND LOGISTIC } \\
\text { - Purchase doctor's } \\
\text { equipment } \\
\text { - Completing medical } \\
\text { records }\end{array}$ & \begin{tabular}{|l} 
OPERATIONS \\
Outpatient \\
- Intensive \\
Care Emergency \\
Central surgery \\
Medical rehabilitation
\end{tabular} & $\begin{array}{l}\text { OUTBOUND } \\
\text { LOGISTIC } \\
\text { - Payment } \\
\text { processing } \\
\text { - Laboratory results }\end{array}$ & $\begin{array}{l}\text { SALES \& } \\
\text { MARKETING } \\
\text { - Hospital website, } \\
\text { posters, weekly } \\
\text { gymnastics, news } \\
\text { about RSUD }\end{array}$ & $\begin{array}{l}\text { SERVICING } \\
\text { - Ambulance } \\
\text { Service \& } \\
\text { Hearse } \\
\text { - SI TOLE }\end{array}$ \\
\hline
\end{tabular}

Figure 2. Analysis of the RSUD Value Chain

Cite: Bintang Janaputra, M. R., Samopa, F., \& Ambarwati Sukmono, R. (2021). The Strategic Planning IS/IT TO Improve Business Competitiveness in Public Hospital. Kinetik: Game Technology, Information System, Computer Network, Computing, Electronics, and Control, 6(1). https://doi.org/10.22219/kinetik.v6i1.1181 


\subsection{External Business Environment Analysis}

The analysis which is done on the environment of external business Hospital is by using analysis PEST and analysis of Porter's Five Forces. Analysis PEST is an analysis that is used to determine the factors of external business any course that may affect hospitals. This analysis focuses on the politics, economy, social, and technology of RSUD [26]. Starting from politics, the influence of political factors has a big impact that can influence the development of the hospital business. It is known that RSUD is a class B teaching hospital under the auspices of the government. For economic factors, RSUD is a Regional Public Service Agency (BLUD) hospital based on the Minister of Home Affairs Regulation Number 79 of 2018. RSUD is fully responsible for managing its finances. Therefore all the needs both from the procurement of medical equipment, construction of services, building development, maintenance, and so on, depend on the income generated. From social factors, RSUD has flexibility in managing finances by implementing healthy business practices to improve services to the community without seeking profit. In order to advance the welfare and educate the surrounding community. In addition to the lower middle class in demand due to the BPJS program, RSUD also develops exclusive services to increase the middle and upper economic community's interest using inpatient services at Graha Gita Husada and outpatient services at the Executive Polyclinic. This makes the middle and upper economic community interested in exclusive services relatively high. In terms of technology, the current rapid development of IS / IT has made hospitals currently competing to develop IS / IT to improve their services, whether web-based, mobile or desktop, such as SI POETRI and SI TOLE.

Porter's Five Forces analysis is used to overcome shortcomings and increase strengths and avoid making inappropriate decisions by the management of dr. Iskak Tulungagung. The analysis of the first five forces porter is Bargaining power from suppliers or suppliers can be said to be low because RSUD cannot make or produce all goods and services on its own and depends on other parties (suppliers or suppliers). Still, it does not depend on one supplier only. The bargaining power of buyers can be said to be moderate. Although there are many other hospitals, the Hospital already has a good image and is cheap compared to other hospitals in Tulungagung. Substitutes Product or Services' threat that gives customers more consideration in making decisions is relatively high. This is judged by the existence of a referral policy for BPJS Kesehatan users. Before going to the RSUD one must get a referral letter from the health facilities, for example, Puskesmas, type C, and D hospitals. People who use BPJS Kesehatan before going to dr. Iskak started the health check at the health facility first. The threat of New Entrants is considered moderate. Several new hospitals were previously clinics or health facilities because they are rapidly turning into hospitals such as Putra Waspada Tulungagung Hospital and Prima Medika Hospital. Competitive Rivalry can be said to be moderate. Although there are many hospitals in Tulungagung such as Orpeha Islamic Hospital, Putra Waspada Tulungagung Hospital, Prima Medika Hospital, Bhayangkara Hospital, Muhammadiyah Bandung Tulungagung Hospital, and Satiti Prima Husada Hospital, none of these hospitals in Tulungagung can compete with RSUD.

\subsection{Internal IS / IT Environmental Analysis}

Phase analysis of the environment of internal IS / IT consists of the identification by the general good of the infrastructure, human resources, and portfolio of applications when these are used in hospitals. Furthermore, all mapped to the analytics McFarlan's Strategic Grid. Analysis McFarlan Here are some lists of IS / IT is used in hospitals based on current conditions can be seen in Table 2.

Table 2. List of IS / IT RSUD Current

\begin{tabular}{|c|c|c|}
\hline No. & Application & User \\
\hline 1 & $\begin{array}{l}\text { BLUD accounting } \\
\text { application }\end{array}$ & Sub. Verification \& Accounting Section \\
\hline 2 & SI IPSRS & $\begin{array}{l}\text { Hospital Facilities \& Infrastructure Maintenance } \\
\text { Installation }\end{array}$ \\
\hline 3 & $\begin{array}{l}\text { pharmacy queue } \\
\text { application }\end{array}$ & Pharmacy Installation \\
\hline 4 & Poly queue application & Polyclinic Installation \\
\hline $\begin{array}{l}5 \\
6\end{array}$ & $\begin{array}{l}\text { SI-POETRI } \\
\text { SITOIF }\end{array}$ & Information Technology Management Installation \\
\hline 6 & SIIOLE & Intormation I echnology Management Installation \\
\hline
\end{tabular}

There are 36 applications used in hospitals, then performed a test of reliability and validity. The validity test results of 36 applications, all values of $r$ count $>0.576$, can be said to be valid. Meanwhile, to test the reliability of the 36 applications obtained are reliable. The final step is to map McFarlan into four parts. The following are results of the mapping can be seen in Table 3.

McFarlan's Strategic Grid applications in RSUD, most of the modules are on support and strategic. Sufficient applications - applications hospitals are entering into the support show the applications that already entered the era of late. There were several road exits when the application enters the support area. The first to evaluate the costs and

(c) 2021 The Authors. Published by Universitas Muhammadiyah Malang

This is an open access article under the CC BY SA license. (https://creativecommons.org/licenses/by-sa/4.0/) 
Kinetik: Game Technology, Information System, Computer Network, Computing, Electronics, and Control

benefits are the next throw or me-reduce application that already is not required. For applications that can still be used, restore, or develop an application with the cost and HR minimum adapted to the application core. Applications are entering the area of strategy is the application that is being and will evolve, the best if the application entry to the area it is continuously doing innovation to increase value-added, continue to carry out repairs to get to the area of the operational key.

Table 3. Mcfarlan's Strategic Grid Hospital Application

\begin{tabular}{|c|c|}
\hline Strategic & High Potential \\
\hline $\begin{array}{l}\text { - } \text { Admissions treasurer } \\
\text { application } \\
\text { - Central cashier application } \\
\text { - Equipment application } \\
\text { - } \text { Bridging E-KTP } \\
\text { - Poly queue application } \\
\text { - Reservation Backend Server } \\
\text { - SI-POETRI } \\
\text { - SITOLE } \\
\text { - SIMRS Modul IGD }\end{array}$ & - $\quad$ SIMRS CSSD \\
\hline $\begin{array}{l}\text { - } \text { Bridging BPJS } \\
\text { - SIMRS Nutrition } \\
\text { - SIMRS Hemodialisa } \\
\text { - SIMRS Rehab Medik } \\
\text { - } \text { Depot pharmacy application } \\
\text { - Warehouse pharmacy } \\
\text { - } \text { application } \\
\text { - Resume Medis Elektronik }\end{array}$ & $\begin{array}{ll}\text { - } & \text { BLUD accounting application } \\
\text { - } & \text { Bridging accounting -SIPKD } \\
\text { - } & \text { SIMRS IPSRS } \\
\text { - } & \text { SIMRS Mutu } \\
\text { - } & \text { SIMRS SDM }\end{array}$ \\
\hline Key Operational & Support \\
\hline
\end{tabular}

\subsection{Analysis of External IS / IT Environment}

Some information technology trends can be applied by RSUD, such as increasing the need for health services ranging from online registration, online drug ordering, and online drug delivery. Then, big data in health care can provide several benefits in the medical world, including lower rates of medical errors, facilitating health prevention, and more accurate predictions. Treatment with the use of virtual reality technology (VR). Some doctors and residents have also used VR to sharpen their skills in the field of surgery. Starting the use of Artificial Intelligence (Al), Al's power will further expand its benefits, such as in the areas of precision medicine, radiology, the latest drug discovery, and genomic science.

\subsection{Future Needs Determination Stage}

Phase initial determination of the need to come with using analysis SWOT performed to determine strengths, weaknesses, opportunities, and threats hospitals. The following is an RSUD SWOT diagram from the results of IFAS and EFAS calculations can be seen in Figure 3.

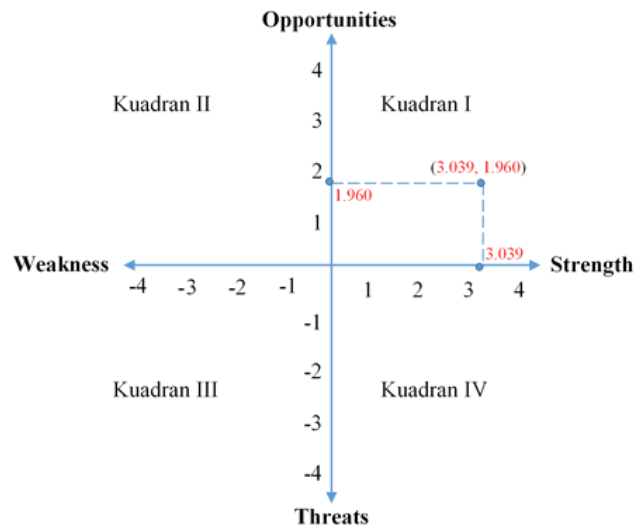

Figure 3. RSUD SWOT Diagram

Cite: Bintang Janaputra, M. R., Samopa, F., \& Ambarwati Sukmono, R. (2021). The Strategic Planning IS/IT TO Improve Business Competitiveness in Public Hospital. Kinetik: Game Technology, Information System, Computer Network, Computing, Electronics, and Control, 6(1). https://doi.org/10.22219/kinetik.v6i1.1181 
The IFAS value obtained was 3,039 , and the EFAS value was 1,960 . Where the IFAS value represents the $X$ coordinate and EFAS represents the $Y$ coordinate. Then, the RSUD in the SWOT quadrant is at point $(3.039,1.960)$, namely, the SO (Strength - Opportunity) quadrant or Expansion in quadrant I is a very favorable situation. Companies, businesses, and marketing strategies have opportunities and strengths to take advantage of current opportunities. Position it signifies Hospital is strong and likely. The strategy should be applied in the condition it is supporting the policy of growth are aggressive (Growth-Oriented Strategy) or with recommendation strategy of progressive, meaning Hospital in a condition fit and strong so it is possible to continue to carry out the Expansion, increase growth and achieve progress in the maximum. Based SO strategies above, then made a table that contains SO strategies were taken from Strength (ST) and Opportunities (OP) [27]. The following is a table of SO strategies in RSUD can be seen in Table 4.

Table 4. RSUD SO Strategy

\begin{tabular}{|c|c|}
\hline No & Analysis Results \\
\hline 1 & Improve the quality of service according to the standard type A hospital service \\
\hline 2 & $\begin{array}{l}\text { It is forming collaborations with various organizations to expand market prey, both } \\
\text { in education and research. }\end{array}$ \\
\hline 3 & $\begin{array}{l}\text { Improve internal hospital conditions such as administration, finance, infrastructure, } \\
\text { and medicine in order to provide the best service for customers }\end{array}$ \\
\hline 4 & Developing leading IS / IT and targeted infrastructure. \\
\hline 5 & $\begin{array}{l}\text { Support and create an integrated system with the central government to comply } \\
\text { with the policies given and reduce the occurrence of errors, and improve the quality } \\
\text { of customer service }\end{array}$ \\
\hline 6 & Increase hospital market share \\
\hline 7 & Utilization of the latest technology such as the use of blockchain, AI, VR and Mobile \\
\hline
\end{tabular}

\subsection{Formulation Strategy}

Determination of formulation strategies includes IS strategic business, IT strategy, and strategic management of IS/IT. From the determination of the strategy formulation, then provides recommendations for the future RSUD application portfolio. Several Hospital IS strategic businesses will utilize IS / IT to achieve its business goals, such as Improving IS Administration in terms of features, usage, and report format. Creating a single ID module as a tool to help make it easier for employees to enter or log in with just one ID. Making Management Dashboard based on the RSUD leadership criteria is presented in a visual form that is carried out easily. SI Dashboard is used to assist RSUD leaders in projecting and monitoring RSUD services. RSUD no longer uses HR applications and administration applications because they are no longer used. Developing Public Relations Information System and making SPPD SI a solution for employees who travel on official trips with still manual and uncontrolled reports.

Discusses IT strategic that will be implemented in the Hospital, such as adding two database servers to accommodate data from applications and optimize the performance of SI applications. Increase the capacity of internet access, build a Command Center, update the SIMRS server and fulfill the needs of a PC and reliable supporting devices for all work units as needed.

In the IS / IT management strategy, the scope of discussion is the RSUD IS / IT management side such as installing WLAN in user-congested locations, regularly checking applications and networks, optimizing application code programs, increasing competence and the number of human resources.

The results of the analysis that has been carried out, it will produce recommendations for future application portfolios as follows can be seen in Table 5 .

Table 5. Future Application Portfolios

\begin{tabular}{ll}
\multicolumn{1}{c}{ Strategic } & \multicolumn{1}{c}{ High Potential } \\
\hline - Payroll application & - Bridging SIMRS - LIS - GDA ONLINE \\
- Tata naskah application & Bridging Laboratorium Information System \\
- SI Management BED & (LIS) - clinical nurse (PK) \\
- Bridging Inventory SIMRS - Inventory BPKAD & - Briding E-KLAIM INA-CBG \\
- SI Lab Patologi Clinic & - SIMRS Modul Applicares \\
- E-RESEP & - Medical Instrument Calibration application \\
- Goods and Services Procurement Document & - Infection Prevention and Control application \\
Storage application & SIMRS Modul Ambulance \\
& - SIMRS Modul SI SPPD \\
& B SIdging SIMRS-SIRANAP \\
\hline
\end{tabular}

(C) 2021 The Authors. Published by Universitas Muhammadiyah Malang

This is an open access article under the CC BY SA license. (https://creativecommons.org/licenses/by-sa/4.0/) 
- Document Template Processor for Procurement of Goods and Services application

- Goods or Services Procurement Numbering application

- Bridging SISRUTE

- Presense Mobile

- Patient satisfaction application
- Bridiging LIS-Microbiology

- Data storage and medical devices Cathlab application

- SI Dashboard Management

$$
\text { Key Operational }
$$

Support

\subsection{Cost-Benefit Analysis}

Three economic criteria will be calculated, Net Present Value, Internal Rate of Return, and Payback Period. The evaluation technique is obtained from identifying information systems, operational costs, and a reduction in operational costs. From the next 25 applications, take an example of a Payroll application with an investment of Rp. 40,000,000. The operational cost can be seen in Table 6.

Table 6. Operational Cost

\begin{tabular}{lcccccc}
\hline A. Investment Cost & \multicolumn{1}{c}{} & \multicolumn{3}{c}{$\mathbf{4 0 . 0 0 0 . 0 0 0}$} \\
\hline B. Cash Flow (in years) & 1 & 2 & 3 & 4 & 5 & \\
\hline Reduction of Operational Cost & 49.800 .000 & 51.154 .560 & 52.545 .964 & 53.975 .214 & 55.443 .340 & \\
\hline Running Cost & 68.206 .864 & 29.406 .864 & 29.406 .864 & 29.406 .864 & 29.406 .864 & \\
\hline Net Cash Flow & -18.406 .864 & 21.747 .696 & 23.139 .100 & 24.568 .350 & 26.036 .476 & $\mathbf{7 7 . 0 8 4 . 7 5 8}$ \\
\hline & & & & & & \\
& & & & in the rupiah currency \\
\hline
\end{tabular}

The investment cost is based on the Identification of System Development Costs, for Reduction of Operational Costs it is based on the utilization of labor costs plus the cost of saving documents and office stationery. Running costs are based on the cost of creating the application plus other costs, then for a net cash flow based on Reduction of Operational Cost minus Running Cost.

\begin{tabular}{ccc} 
& Table 7. Economic Criteria for Payroll Application \\
\hline No. & Economic Criteria & Analysis Results \\
\hline 1 & Net Present Value & Rp. 25.379 .850 \\
2 & Payback period & Three years six month \\
3 & Internal rate of return & $16,72 \%$ \\
\hline
\end{tabular}

Based on economic criteria for payroll application in Table 7, the NPV value of the net benefit is Rp. $25,379,850$, it can be seen that the NPV is more than 0 or has a positive value. So it can be concluded that the second criterion used to select the best alternative in the feasibility study by maximizing the NPV of net benefits has been fulfilled or can be said to be feasible. After doing trial and error to find a negative NPV value, then after that, calculations are carried out to get the percentage of IRR obtained. The IRR value is $16.72 \%$. So it can be concluded that the third criterion used to select the best alternative in the feasibility study, namely maximizing the fulfilled or feasible IRR due to the calculation result is greater than $4 \%$ (the interest rate applies based on the $\mathrm{BI}-7$ day (reverse) Repo Rate issued by Bank Indonesia).

The net cash flow value per year from calculating the difference between reduced operating costs and current costs is entered into the Payback Period table along with the investment value. The calculation is then done to get the value of the payback period for the investment that has been issued. It is known that the initial investment value of the Payroll application is Rp. 40,000,000, resulting in a payback period of 3 years 6 months. This means that the payback time is faster than the time set by the Hospital, given the economic age of 5 years. Many as 25 future application portfolios, calculated using Three economic criteria Analysis and show that all recommendations are feasible based on identifying system development costs, identifying current costs, reducing operating costs.

The results of this study are in line with several previous studies that carried out IS / IT strategic planning using the Ward \& Peppard method with the addition of Value Chain analysis, Critical Success Factor (CSF), and Gap analysis such as Sriminangga's research. There are also those who add a Balance Scorecard to the Ward \& Peppard method such as the research of Setiawan and Hannesto. Adding a SWOT analysis to analyze internal business such as Christianti's research, or in addition to adding a SWOT analysis, also adding a McFarlan Strategic Grid to assess or map the latest applications that fall into the high potential, strategic, operational key or support categories as in Budiyanto's research. Or by adding the Ward \& Peppard method to the Anita Cassidy method such as Lestari research. where all the research results are in the form of IS business strategy, IT strategy, IS application portfolio. It's just that

Cite: Bintang Janaputra, M. R., Samopa, F., \& Ambarwati Sukmono, R. (2021). The Strategic Planning IS/IT TO Improve Business Competitiveness in Public Hospital. Kinetik: Game Technology, Information System, Computer Network, Computing, Electronics, and Control, 6(1). https://doi.org/10.22219/kinetik.v6i1.1181 
this financial aspect has not been touched by previous research, because it only focuses on strategic planning that produces portfolios. Current research shows that all portfolios obtained are feasible in financial aspects.

\section{Conclusion}

The results of this research are IS business strategy, IT business strategy, IS / IT management strategy, and recommendations for future application portfolios by considering costs and benefits. There are 25 recommendations for new or future application portfolios according to the NPV, IRR, and PP criteria, which show all the recommendations are feasible based on current costs, direct savings benefits, and reduced hospital operating costs. Among them are Payroll application, the numbering of procurement of goods, bridging LIS-PK, Mobile presence, and BED management. This innovation is what makes RSUD achieve and maintain a competitive advantage to be the best.

The limitation of this study is that all of the 25 portfolios are feasible based on economic criteria. However, the RSUD has limited funds each year. Due to limited funding, all applications can't be absorbed by the RSUD even though all applications are feasible. In the future, this research can be added with a ranking of 25 portfolios by adding the Multi Criteria Decision Making (MCDM) method. This ranking is intended to provide an overview of the RSUD, which takes precedence.

\section{References}

[1] Kementerian Kesehatan Republik Indonesia, "Klasifikasi dan Perizinan Rumah Sakit," PMK No. 3, BN.2020/NO.21. 2020.

[2] Kemenkes Republik Indonesia "Fasyankes Online."2020.

[3] Ambarwati, R., Saputro, A., \& Fathurochman, A. G." Product Development for Competitive Advantage of Micro, Small, and Medium Enterprises of Ikat Woven Fabric in Kediri," Binus Business Review, 10(2), 75-86. 2019. https://doi.org/10.21512/bbr.v10i2.5676

[4] Išoraitè, M. "The competitive advantages theoretical aspect," Ecoforum Journal, 7(1). 2018.

[5] Agwunobi, A., \& Osborne, P. "Dynamic capabilities and healthcare: a framework for enhancing the competitive advantage of hospitals," California Management Review, 58(4), 141-161, 2016. https://doi.org/10.1525/cmr.2016.58.4.141

[6] Nabelsi, V., \& Gagnon, S. "Information technology strategy for a patient-oriented, lean, and agile integration of hospital pharmacy and medical equipment supply chains," International Journal of Production Research, 55(14), 3929-3945, 2017. https://doi.org/10.1080/00207543.2016.1218082

[7] Mugo, P. "Porter's Five Forces Influence on Competitive Advantage in Telecommunication Industry in Kenya," European Journal of Business and Strategic Management, 5(2), 30-49, 2020. https://doi.org/10.47604/ejbsm.1140

[8] Kaleka, A., \& Morgan, N. A. "Which competitive advantage(s)? Competitive advantage-Market performance relationships in international markets," Journal of International Marketing, 25(4), 25-49, 2017. https://doi.org/10.1509/jim.16.0058

[9] Jarsa, V., \& Christianto, K. "IT Governance Audit with COBIT 5 Framework on DSS Domain". Kinetik: Game Technology, Information System, Computer Network, Computing, Electronics, and Control, 3(4), 279-286. 2018. https://doi.org/10.22219/kinetik.v3i4.665

[10] J. Ward and J. Peppard, Strategic Planning for Information Systems, 3rd ed. Chichester, West Sussex, England: John Wiley \& Sons Inc, 2002.

[11] Sriminangga, N. P., \& Samopa, F. "Strategic Planning of Information Systems/Information Technology at KOMINFO Department in Malang. International Journal of Education and Research, 5(1). 2017.

[12] Hannesto, R., \& Surya, M. M "Information system strategic planning in XYZ foundation at learning and development division". International Conference on Information Management and Technology (ICIMTech) (pp. 31-34). IEEE. 2017. https://doi.org/10.1109/ICIMTech.2017.8273506

[13] Setiawan, A., \& Yulianto, E. "Information System Strategic Planning Using IT Balanced Scorecard in Ward \& Peppard Framework Model. "International Journal of Engineering and Technology (IJET). p1864-1872. India. 2017. https://dx.doi.org/10.21817/ijet/2017/v9i3/170903134

[14] Christianti, N. "Information system strategic planning in PT XYZ." International Conference on Applied Computer and Communication Technologies (ComCom), pp. 1-8. IEEE, 2017. https://doi.org/10.1109/COMCOM.2017.8167095

[15] Ismanto, M. A., Kusumawardhana, V. H., \& Warnars, H. L. H. S.Strategic Planning Of Information Systems And Information Technology At Agricultural Research And Development Agency, Ministry Of Agriculture." In 2018 Indonesian Association for Pattern Recognition International Conference (INAPR), pp. 267-273. IEEE, 2018. https://doi.org/10.1109/INAPR.2018.8627011

[16] Budiyanto, D., \& Setyohadi, D. B."Strategic information system plan for the implementation of information technology at Polytechnic "API" Yogyakarta." In 2017 5th International Conference on Cyber and IT Service Management (CITSM), pp. 1-6. IEEE, 2017. https://doi.org/10.1109/CITSM.2017.8089267

[17] Febriyanti, K. D., Samopa, F., \& Ambarwati, R. "Strategic Planning for IS/IT of XYZ Internet Service Provider Using Ward and Peppard Method". IPTEK Journal of Proceedings Series, (5), 473-479. 2019. http://dx.doi.org/10.12962/j23546026.y2019i5.6407

[18] Lestari, N. S., Mahardika, A. G., Sujana, A., Adinda, N. R., \& Lie, I. D. "Strategic Planning Information System Using Ward and Peppard Method with Anita Cassidy Method." In Journal of Physics: Conference Series Vol. 1424, No. 1, p. 012024. IOP Publishing. 2019. https://doi.org/10.1088/1742-6596/1424/1/012024

[19] Flanagan, D. J., Lepisto, D. A., \& Ofstein, L. F. "Coopetition among nascent craft breweries: a value chain analysis." Journal of Small Business and Enterprise Development. 2018. https://doi.org/10.1108/JSBED-05-2017-0173

[20] Kanakulya, E. K., \& Jinzhao, W. A. N. G. The Status of Africa's Construction Industry and its Porter's Five Forces Analysis. International Business and Management, 14(2), 50-53. 2017. http://dx.doi.org/10.3968/9611

[21] Maulani, G. A. F., \& Mubarok, T. M. S. "Strategic Planning of Information Systems for Mosque in Indonesia." Business Innovation and Entrepreneurship Journal, 2(2), 107-111. 2020. https://doi.org/10.35899/biej.v2i2.90

[22] Girinata, I. M. C., \& Suryani, E. Strategic Planning for Systems \& Information Technology of XYZ Hospital Using Ward and Peppard Method. IPTEK Journal of Proceedings Series, (5), 452-459. 2019. http://dx.doi.org/10.12962/j23546026.y2019i5.6392

[23] Michelle, O., \& Wijaya, A. F. "Strategic Planning for IS/IT Using Ward and Peppard at Maman Elektronik Sokaraja," INTENSIF: Jurnal IImiah Penelitian dan Penerapan Teknologi Sistem Informasi, 4(2), 272-282. 2020. https://doi.org/10.29407/intensif.v4i2.14494

[24] Gaol, F. L., Rahayu, S., \& Matsuo, T. "The Development of Information System with Strategic Planning for Integrated System in the Indonesian Pharmaceutical Company". Open Engineering, 10(1), 721-732. 2020. https://doi.org/10.1515/eng-2020-0081

[25] Hakim, M. M. Information System Strategic Planning in IS/IT Service Provider. JIPI (Jurnal IImiah Penelitian dan Pembelajaran Informatika), 2(2). 2017. http://dx.doi.org/10.29100/jipi.v2i2.395

(C) 2021 The Authors. Published by Universitas Muhammadiyah Malang

This is an open access article under the CC BY SA license. (https://creativecommons.org/licenses/by-sa/4.0/) 
[26] Yang, S., Zhu, X., \& Guo, W. "Cost-benefit analysis for the concentrated solar power in China." Journal of Electrical and Computer Engineering, 2018. https://doi.org/10.1155/2018/4063691

[27] Kouskoukis, M. N., \& Botsaris, C. "Cost-benefit analysis of telemedicine systems/units in Greek remote areas." PharmacoEconomics-Open, 1(2), 117-121. 2017. https://doi.org/10.1007/s41669-016-0006-z

[28] Maravas, A., \& Pantouvakis, J. P. "A New Approach to Studying Net Present Value and the Internal Rate of Return of Engineering Projects under Uncertainty with Three-Dimensional Graphs". Advances in Civil Engineering, 2018. https://doi.org/10.1155/2018/6108680

[29] Arjunan, K. "Validity of NPV Rule and IRR Criterion for Capital Budgeting and CBA". Available at SSRN 3505058. 2019. https://dx.doi.org/10.2139/ssrn.3505058

Cite: Bintang Janaputra, M. R., Samopa, F., \& Ambarwati Sukmono, R. (2021). The Strategic Planning IS/IT TO Improve Business Competitiveness in Public Hospital. Kinetik: Game Technology, Information System, Computer Network, Computing, Electronics, and Control, 6(1). https://doi.org/10.22219/kinetik.v6i1.1181 
